\title{
Measurement of in vivo proliferation in human colorectal mucosa using bromodeoxyuridine
}

\author{
C S Potten, M Kellett, S A Roberts, D A Rew, G D Wilson
}

\begin{abstract}
In vivo bromodeoxyuridine (BrdUrd) labelling of the human large bowel was performed and a detailed histochemical localisation of label in sections of crypts was undertaken using a monoclonal antibody to BrdUrd containing DNA. Flow cytometric studies on extracted nuclei were also performed (data presented elsewhere). The average crypt in the human large bowel (excluding the rectum) was 82 cells in height and 41 cells in circumference, with a total of about 2000 cells (assuming a topographical correction factor of $0 \cdot 6$ ). Ten per cent of the cells were replicating their DNA - that is, were in the $\mathbf{S}$ phase of the cell cycle and $0.4 \%$ were in mitosis. The median position for the labelling index versus cell position frequency plot is at the 20 th cell position - at a quarter of the crypt height. The lower and upper limits of the cell proliferation are given by the 5th and 95th percentiles at cell positions 4 and 43 respectively. The peak labelling index is about $30 \%$ and it occurs at cell position 15 . The labelling index at the crypt base, the probable stem cell zone, is about $14 \%$, suggesting that these cells have a longer cell cycle. Taking a value of 8.6 hours for the duration of the $S$ phase (deduced from the flow cytometric data) and assuming a growth fraction of 1.0 for the mid-crypt, these data provide an estimate of about 30 hours for the cell cycle time. The rectal crypts are about the same size but contain about $30 \%$ fewer $S$ phase cells. The data also yielded a per cent BrdUrd labelled mitosis curve.
\end{abstract}

CRC Departments of Epithelial Biology

CS Potten

M Kellett

and Biomathematics, Paterson Institute for Cancer Research, Christie Hospital, Manchester M20 9BX S A Roberts

University Surgical Unit, University of Southampton, Faculty of Medicine, Southampton General Hospital D A Rew

CRC Gray Laboratory, Mount Vernon Hospital, Northwood, Middlesex Horthwood,

HA6 2RN
G D Wilson

Correspondence to:

Dr C S Potten.

Accepted for publication 29 April 1991
The study of the proliferation of gastrointestinal mucosa may provide clues to the development of disease states such as invasive adenocarcinoma. In the past cell kinetic data for human colorectal mucosa have been obtained mainly from in vitro radioisotope studies using tritiated thymidine, and vincristine induced metaphase arrest. In and technical constraints. However, the principles of mucosal proliferation have been well characterised in animal studies, particularly of the mouse and rat colon. ${ }^{1-3}$ Parameters which have been studied include the distribution of $S$ phase (proliferating) cells within crypts, mitotic indices, and crypt dimensions. The sequence of migration and differentiation of cells from the bottom of the crypts to the tip of the villus has also been studied.

Human mucosal proliferation may be modified in benign and malignant states - for example, in the mucosa of patients with ulcerative colitis, familial polyposis coli, and villous adenomas. ${ }^{+7}$ Mucosal cell kinetics may also be vivo studies have been severely limited by ethical modified by radiotherapy and endocrine, metabolic, or dietary changes. ${ }^{910}$ The kinetics of normal mucosa may change with the presence and proximity of a tumour. ${ }^{11-13}$ There may also be a change in proliferation with anatomical site along the colon..$^{101314}$

The labelling index of human colorectal mucosa has been measured using both in vitro and in vivo techniques, but these studies frequently involve only a few patients and rarely provide data on anatomical, or microscopical, topographical changes. In some studies dynamic data have been calculated (Table I). Human colonic epithelial cells are believed to migrate from the crypt base over a period of three to eight days. ${ }^{15}$

The clinical study of cell proliferation has been substantially aided by the use of bromodeoxyuridine (BrdUrd) and monoclonal antibodies to DNA containing BrdUrd as an alternative to 3HTdR for studies of animal and human mucosal cell kinetics. ${ }^{91617}$ The uses and safety of this drug in the study of tumour proliferation in vivo have been established.

Risio $e$ e $a l^{17}$ reported on the in vitro BrdUrd labelling index of human mucosa, metaplastic polyps, dysplastic adenomas, and carcinomas. Khan et $a l^{18}$ infused BrdUrd into 14 patients with metastatic colonic adenocarcinoma. Biopsy specimens of tumour and normal mucosa were excised two hours later. Labelling was of good quality and highly specific. The labelling index of the mucosa had a mean value of $11 \%$ (range 3.6-20.0\%).

In vivo BrdUrd labelling when combined with multiparameter flow cytometric analysis is an established technique which allows dynamic data on tumour cell kinetics to be obtained from a single injection and biopsy. ${ }^{19-22}$ The data obtained include the DNA index (the proportion of $S$ phase cells) and the $S$ phase duration $\left(T_{s}\right)$ of the cells within the tissue or tumours. We have adapted this technique to the clinical study of human mucosal proliferation.

We have used both flow cytometric and static histochemical analyses to study the spatial distribution of $S$ and $M$ phase cells in the crypt, the crypt cell labelling index, and the crypt cell turnover rate in the normal colon and rectum. The cell cycle of the mid-crypt cells has also been estimated. The evaluation of the method which we report was undertaken on tissues excised from surgical resection specimens from patients who had consented to an in vivo labelling study of their colorectal primary adenocarcinoma. ${ }^{22}$ The technique was used to study the changes in proliferation along the normal large bowel. It has wider applications in both clinical and experimental investigations of proliferative changes in diseased state. 
TABLE I Published data on cell kinetics of human large bowel

\begin{tabular}{|c|c|c|c|c|c|}
\hline Site & $\begin{array}{l}\text { No of } \\
\text { patients }\end{array}$ & Technique & $\begin{array}{l}\text { Labelling } \\
\text { index }(\%) \\
(\text { mean }(S D))\end{array}$ & $\begin{array}{l}\text { Sphase } \\
\text { duration }(h) \\
(\text { mean }(S D))\end{array}$ & Other information \\
\hline Rectum $^{33}$ & 1 & 3HTdR in vivo & - & - & $\begin{array}{l}\text { Peak labelling index }=\sim 40 \% \text { at } \\
\text { cp } 18-45\end{array}$ \\
\hline Colon $^{33}$ & 1 & $\begin{array}{l}\text { 3HTdR in vivo PLM } \\
\text { colostomy }\end{array}$ & - & 22 & $\mathrm{~T}_{\mathrm{c}}=39$ hours \\
\hline Rectum $^{6}$ & 8 & $3 \mathrm{HTdR}$ in vitro $(6 \mathrm{~h})$ & $4 \cdot 8$ & - & In lower $2 / 3$ \\
\hline Colorectal $^{34}$ & $\begin{array}{l}5 \\
7\end{array}$ & $\begin{array}{l}\text { 3HTdR in vitro } \\
3 \mathrm{HTdR} \text { in vitro }\end{array}$ & $\begin{array}{l}8 \cdot 3(1 \cdot 0) \\
8 \cdot 7(1 \cdot 0)\end{array}$ & $\begin{array}{l}- \\
-\end{array}$ & $\begin{array}{l}\text { Normal subjects } \\
\text { Normal in cancer patients }\end{array}$ \\
\hline Colorectal $^{35}$ & $\begin{array}{l}13 \\
13\end{array}$ & $\begin{array}{l}3 \mathrm{HTdR} \text { in vitro } \\
3 \mathrm{HTdR} \text { in vitro }\end{array}$ & $\begin{array}{l}7.9(0.9) \\
9 \cdot 8(1.2)\end{array}$ & $\begin{array}{l}- \\
-\end{array}$ & $\begin{array}{l}60 \text { cells } / \text { column, normal subjects } \\
\text { Normal in cancer patients }\end{array}$ \\
\hline Colorectal $^{36}$ & 8 & $3 \mathrm{HTdR}$ in vitro & $17 \cdot 0(2 \cdot 0)$ & $11 \cdot 2(0 \cdot 9)$ & $\mathrm{T}_{\mathrm{T}}=73(6)$ hours \\
\hline Colon $^{27}$ & 3 & $\begin{array}{l}\text { Flow cytometry DNA } \\
\text { distributions (SI) }\end{array}$ & $15 \cdot 2(1 \cdot 9)$ & - & $\begin{array}{l}23 \cdot 7 \% \text { mucus cells, } 2500 \text { cells per } \\
\text { crypt }\end{array}$ \\
\hline Rectum $^{27}$ & 3 & $\begin{array}{l}\text { Flow cytometry DNA } \\
\text { distributions (SI) }\end{array}$ & $16 \cdot 4(4 \cdot 9)$ & - & \\
\hline $\begin{array}{l}\text { Colon }^{37} \\
\text { Colon }^{11} \\
\text { Colon }^{38} \\
\text { Rectum }^{38+6}\end{array}$ & $\begin{array}{l}4 \\
1 \\
\text { Review } \\
\text { Review }\end{array}$ & $\begin{array}{l}\text { 3HTdR in vitro } \\
\text { 3HTdR in vitro } \\
\text { In vivo } \\
\text { In vivo } \\
\text { In vitro }\end{array}$ & $\begin{array}{l}11 \cdot 7(4 \cdot 0) \\
35 \cdot 1(2 \cdot 8) \\
12-18 \\
18-25 \\
1-17\end{array}$ & $\begin{array}{l}10 \cdot 1(0 \cdot 5) \\
11-20 \\
9-14 \\
7-11\end{array}$ & $\begin{array}{l}\text { Range } 6 \cdot 2-18 \cdot 2 \% \\
\text { Double labelling }\end{array}$ \\
\hline Rectum $^{39}$ & 3 & $3 \mathrm{HTdR}$ in vivo & - & 14 & $\begin{array}{l}\mathrm{T}_{\mathrm{T}}>19 \cdot 5 \text { hours; flux } 1.3 \text { cells } / \\
100 \text { cells } / \mathrm{h} \text { velocity } 0.9 \text { cell } \\
\text { positions } / \mathrm{h}\end{array}$ \\
\hline $\begin{array}{l}\text { Colon } \\
\text { Rectum } \\
\text { Colon }^{42+4}\end{array}$ & $\begin{array}{l}2 \\
2 \\
3\end{array}$ & $\begin{array}{l}\text { 3HTdR in vivo PLM } \\
\text { 3HTdR in vivo PLM } \\
\text { 3HTdR in vivo PLM }\end{array}$ & $\begin{array}{l}14-17 \\
16 \cdot 7 \\
12-18\end{array}$ & $\begin{array}{l}11-14 \\
12 \\
11-14\end{array}$ & $\begin{array}{l}\text { Velocity } 1.0 \text { cell position/hour } \\
1.2 \text { cell positions/hour }\end{array}$ \\
\hline Colon $^{13}$ & 16 & $3 \mathrm{HTdR}$ in vitro & $4 \cdot 9(0 \cdot 2)$ & - & Crypt length $41 \cdot 3$ \\
\hline Rectal mucosa $a^{43}$ & 11 & $\begin{array}{l}\text { Stathmokinetics VCR in } \\
\text { vivo }\end{array}$ & - & - & $\begin{array}{l}13 \cdot 8 \text { cells } / 1000 \text { cells } / \mathrm{h} . \mathrm{T}=85 \\
\text { h.growth fraction } 0 \cdot 28-0 \cdot 56\end{array}$ \\
\hline Rectal mucosa & 7 & $3 \mathrm{HTdR}$ in vitro & $13 \cdot 1$ & - & $\begin{array}{l}\text { Labelling index }=19 \cdot 0 \text { in } \\
\text { ulcerative colitis }\end{array}$ \\
\hline \multirow[t]{3}{*}{ Rectal mucosa ${ }^{31}$} & 11 & $3 \mathrm{HTdR}$ in vitro & $9 \cdot 5(0 \cdot 3)$ & - & $\begin{array}{l}30-50 \text { years old, } 43 \cdot 6 \text { cells } / \\
\text { column }\end{array}$ \\
\hline & 11 & $3 \mathrm{HTdR}$ in vitro & $9 \cdot 3(0 \cdot 3)$ & - & $\begin{array}{l}51-65 \text { years old, } 45 \cdot 7 \text { cells/ } \\
\text { column }\end{array}$ \\
\hline & 8 & $3 \mathrm{HTdR}$ in vitro & $12 \cdot 9(0 \cdot 5)$ & - & $\begin{array}{l}66-90 \text { years old, } 46.6 \text { cells/ } \\
\text { column }\end{array}$ \\
\hline Rectal mucosa ${ }^{5}$ & 8 & $\begin{array}{l}\text { 3HTdR double label } \\
\text { in vitro }\end{array}$ & $9 \cdot 5$ & $7 \cdot 9$ & Turnover time $=90$ hours \\
\hline $\begin{array}{l}\text { Colonic mucosa }{ }^{18} \\
\text { Colon (descending) }\end{array}$ & $\begin{array}{r}8 \\
10\end{array}$ & $\begin{array}{l}\text { BrdUrd in vivo } \\
\text { BrdUrd in vitro }\end{array}$ & $\begin{array}{l}10 \cdot 5 \\
5 \cdot 7(0 \cdot 7)\end{array}$ & - & $\begin{array}{l}\text { Hyperplasia labelling index }=6 \cdot 3 \\
\text { Adenoma labelling index }=16 \cdot 7 \\
\text { Carcinoma labelling index }=21 \cdot 2\end{array}$ \\
\hline
\end{tabular}

$3 \mathrm{HTdR}=$ tritiated thymidine; $\mathrm{T}_{\mathrm{C}}=$ cell cycle duration; $\mathrm{T}_{\mathrm{T}}=$ turnover time; $\mathrm{SI}=\mathrm{S}$ phase index; $\mathrm{PLM}=$ per cent bromodeoxyuridine labelled mitosis curve.

\section{Methods}

PATIENTS, DRUG ADMINISTRATION, AND TISSUE SAMPLES

Patients (aged 45-86 years) selected for the study consented to reveive a single intravenous dose of $250 \mathrm{mg}$ 5-bromo-2'-deoxyuridine (BrdUrd) (Takeda, Japan) administered over 30 seconds in $10 \mathrm{ml}$ saline, between 2.4 and 16 hours before surgery. No toxicity was associated with this procedure. Hospital ethical committee approval was obtained. A total of 147 samples were obtained from 75 patients. Mucosal strips were excised from conventional surgical resection specimens of colon and rectum, which included both the primary tumour and up to $30 \mathrm{~cm}$ of normal bowel. The principles governing selection of specimens for the present study were that the mucosa was macroscopically normal, and that mucosal specimens were more than $5.0 \mathrm{~cm}$ from a primary tumour to reduce the risk of tumour infiltration of the specimen.

Strips of mucosa measuring $3.0 \times 1.0 \mathrm{~cm}$ were dissected with scissors from the submucosa and stored in $70 \%$ ethanol at $-20^{\circ} \mathrm{C}$ in a commercial freezer within 30 minutes of excision. These samples were then processed for the immunohistochemical detection of BrdUrd positive cells in the crypts of normal mucosa. Samples of caecum, ascending (right) colon, transverse colon, descending (left) colon, sigmoid colon,

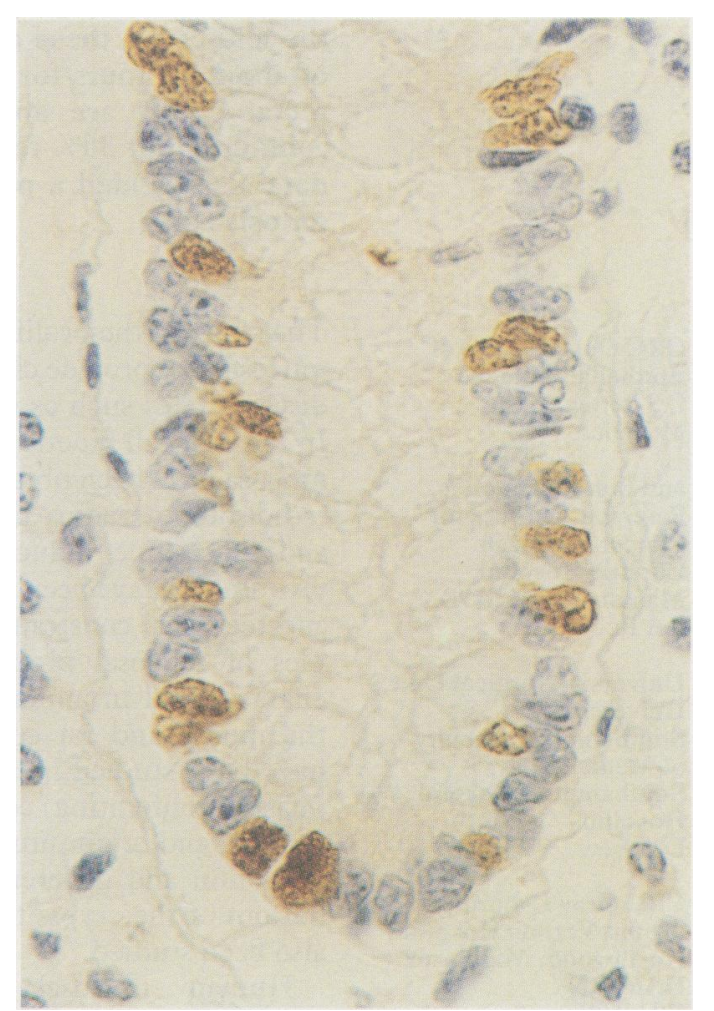

Figure 1: Photomicrograph of a normal colonic crypt labelled with the BrdUrd monoclonal antibody (brown reaction product). Haematoxylin and eosin, original magnification $\times 1000$. 
rectosigmoid junction, and rectum were analysed separately.

\section{TISSUE PROCESSING STAINING AND IMMUNOHISTOCHEMICAL LOCALISATION OF BrdUrd}

Pieces of tissue were removed from the cold $70 \%$ ethanol and were placed in $10 \%$ formol saline overnight. The samples were embedded in paraffin and several $3 \mu \mathrm{m}$ sections (every fourth section) were cut and placed on gelatinised slides. The dewaxed slides were air dried and the endogenous peroxidase activity was blocked with $1 \%$ hydrogen peroxide in methanol for 30 minutes. The slides were then hydrolysed in $1 \mathrm{~N}$ $\mathrm{HCl}$ at $60^{\circ} \mathrm{C}$ for 8 minutes and then neutralised in boric acid buffer. After washing in phosphate buffered saline (PBS) the sections were covered with normal rabbit serum diluted 1 in 20 in PBS for 30 minutes and were kept moist. The primary antibody (rat anti-BrdUrd BU1/75, 1CR1, from Sera Labs, Crawley Down, Sussex) was then added ( 1 in 5 in PBS) for one hour at $20^{\circ} \mathrm{C}$. This was followed by washing and the addition of the secondary antibody (rabbit anti-rat peroxidase, Dako, High Wycombe, Bucks) 1 in 100 in $10 \%$ normal mouse serum for one hour at $20^{\circ} \mathrm{C}$. The slides were then rewashed and treated with diamino-benzidine tetrahydrochloride (Sigma, Poole) for 15 minutes in the dark. Finally, the slides were weakly stained with haematoxyalin for one minute before dehydrating in alcohol and mounting in Xam (BDH, Poole) under a coverslip. An example is shown in Figure 1.

\section{SCORING AND METHOD OF COUNTING OF STAINED} SECTIONS

The counting of labelled crypts and subsequent data analysis is laborious. A proprietary software

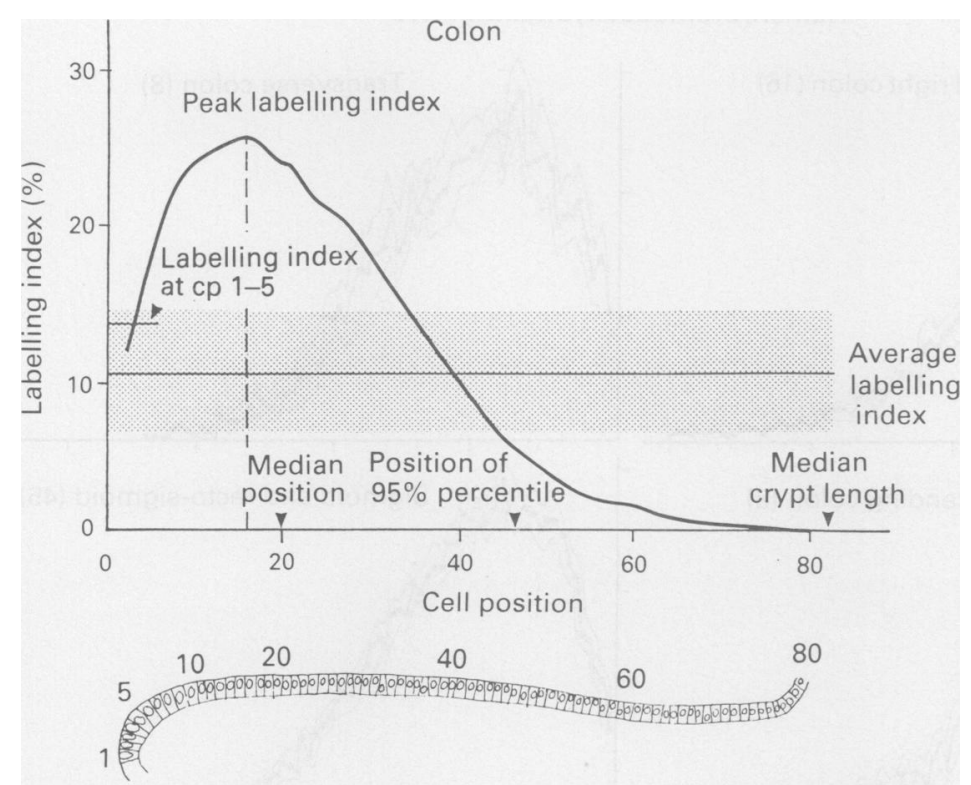

Figure 2: Example of a typical frequency plot for the labelling index against cell position in the crypt. This distribution is based on the average distribution obtained for all colonic sites pooled together (77 samples) and has been smoothed over three cell positions. The base of the crypt is to the left, cell position 1, and the top of the crypt to the right. Fifty half crypt sections were scored per sample and the mean distribution per sample was then obtained. Note that the pooled distribution shows a lower peak height than the individual distributions. This is due to pooling distributions with differing peak positions. package developed at the Paterson Institute has led to substantial improvement in the productivity and analytical facilities of crypt counting (SA Roberts, et al, unpublished). Data are recorded by the researcher directly into a BBC Microcomputer using four keys to record unlabelled, labelled, mitotic, and labelled mitotic cells. The data are recorded and stored according to cell position in the crypt for further analysis and direct comparisons, including aggregate data from multiple crypts. ${ }^{23}$ One such labelling index frequency plot is shown in Figure 2.

As well as producing histograms, the program was used to compute for each sample the overall mean labelling index, the mean labelling index for the first five positions, the 5th and 95th percentiles of the labelling index distribution, the median crypt length, the mitotic index, and measures of the peak of the labelling index distribution and runs of labelled cells. The distribution peak height and position were determined from the maximum of the 5-position moving average of the distribution; the moving average being used to smooth out the fluctuation caused by the statistical fluctuations in cell counts.

A run of labelled cells is a series of labelled cells in consecutive positions, and the run distributions give information about the clustering of labelled cells in a crypt. Two measures of this clustering are used here: (i) the percentage of labelled cells which are in a run of more than one cell - that is, the percentage in clusters; (ii) the median number of runs per crypt.

Good longitudinal sections of crypts are necessary for scoring, which was achieved using a x40 oil objective under normal transmitted light or under phase contrast in a few cases when the BrdUrd staining was weak. Sections of crypts were selected for scoring if they possessed a lumen and the crypt base was at a maximum depth in comparison with all other crypts. No unambiguous marker for the crypt base was present. The mid-point at the crypt base was identified and the crypt was divided into two equal longitudinal halves (Fig 2). The lowermost cell nucleus in each half was designated a cell position one as a reference point for the computer programme. Fifty half-crypt sections were scored from each sample. The scoring was performed for each cell position (identified by the nucleus) along the crypt column up to the mid-point on the intercrypt proximal table of cells if a neighbouring crypt was present, or up to the ninth cell position past the neck of the crypt if no neighbouring crypt was present.

\section{FLOW CYTOMETRIC ANALYSIS}

Strips of mucosa for flow cytometry were stored in $70 \%$ ethanol. After mincing the tissue, fragments of mucosa were incubated in porcine pepsin (Sigma) $(0.4 \mathrm{mg}$ per ml) in $0.1 \mathrm{~mol} / 1 \mathrm{HCl}$ for 45 minutes at $37^{\circ} \mathrm{C}$. After filtration through $35 \mu \mathrm{m}$ nylon mesh nuclei were resuspended in $3 \mathrm{ml} 2 \mathrm{~mol} / 1 \mathrm{HCl}$ for 13 minutes at $37^{\circ} \mathrm{C}$. Nuclei were then washed twice in $5 \mathrm{ml}$ PBS. The concentration of nuclei was adjusted to 2 million per $\mathrm{ml}$. Nuclei were resuspended in a solution of 
TABLE II Analysis of proliferative indices in human colorectal crypt sections using bromodeoxyuridine labelling in vivo (mean (SD))

\begin{tabular}{|c|c|c|c|c|c|c|c|c|c|c|c|}
\hline \multirow[b]{2}{*}{ Area } & \multirow[b]{2}{*}{$\begin{array}{l}\text { No of } \\
\text { samples }\end{array}$} & \multicolumn{10}{|c|}{ Labelling index $(\%)$} \\
\hline & & Overall & Maximum ${ }^{\star}$ & $\begin{array}{l}\text { Position of } \\
\text { maximum }^{\star}\end{array}$ & $\begin{array}{l}\text { Mean for } \\
1-5 \% \text { cell } \\
\text { position }\end{array}$ & $\begin{array}{l}\text { Position of } \\
\text { 95th } \\
\text { percentile }\end{array}$ & $\begin{array}{l}\text { Median } \\
\text { crypt length } \\
\text { (cells) }\end{array}$ & $\begin{array}{l}\text { Overall } \\
P L M(\%)\end{array}$ & $\begin{array}{l}\text { Overall } \\
\text { mitotic } \\
\text { index }(\%)\end{array}$ & $\begin{array}{l}\% \text { Labelled } \\
\text { cells in runs } \\
>1 \text { cell }\end{array}$ & $\begin{array}{l}\text { Median No } \\
\text { of cells/run }\end{array}$ \\
\hline $\begin{array}{l}\text { Caecum and right colon } \\
\text { (ascending) } \\
\text { Transverse colon } \\
\text { Left colon (descending) } \\
\text { Sigmoid and rectosigmoid }\end{array}$ & $\begin{array}{r}16 \\
8 \\
8\end{array}$ & $\begin{array}{r}9 \cdot 7(3 \cdot 5) \\
9 \cdot 8(2 \cdot 9) \\
10 \cdot 0(3 \cdot 2)\end{array}$ & $\begin{array}{l}25 \cdot 7(8 \cdot 3) \\
27 \cdot 7(4 \cdot 7) \\
29 \cdot 8(6 \cdot 1)\end{array}$ & $\begin{array}{l}16 \cdot 0(6 \cdot 3) \\
17 \cdot 9(4 \cdot 4) \\
11 \cdot 5(5 \cdot 3)\end{array}$ & $\begin{array}{l}13 \cdot 6(7 \cdot 6) \\
14 \cdot 6(6 \cdot 0) \\
15 \cdot 8(8 \cdot 1)\end{array}$ & $\begin{array}{l}45 \cdot 9(11 \cdot 0) \\
42 \cdot 0(5 \cdot 6) \\
40 \cdot 9(10 \cdot 6)\end{array}$ & $\begin{array}{l}82 \cdot 5(11 \cdot 5) \\
83 \cdot 1(8 \cdot 0) \\
79 \cdot 4(11 \cdot 9)\end{array}$ & $\begin{array}{l}37 \cdot 2(23 \cdot 4) \\
44 \cdot 8(21 \cdot 9) \\
50 \cdot 6(24 \cdot 4)\end{array}$ & $\begin{array}{l}0.38(0.17) \\
0.45(0.29) \\
0.36(0.24)\end{array}$ & $\begin{array}{l}41 \cdot 4(14 \cdot 5) \\
45 \cdot 1(9 \cdot 6) \\
47 \cdot 9(10 \cdot 9)\end{array}$ & $\begin{array}{l}0.93(0.29) \\
0.94(0.15) \\
1.02(0.25)\end{array}$ \\
\hline $\begin{array}{l}\text { junction } \\
\text { Pooled data for colon } \\
\text { Rectum } \\
\text { Significant differences }\end{array}$ & $\begin{array}{l}45 \\
77 \\
30\end{array}$ & $\begin{array}{r}11 \cdot 0(4 \cdot 9) \\
10 \cdot 5(4 \cdot 3) \\
7 \cdot 7(3 \cdot 8)\end{array}$ & $\begin{array}{l}29 \cdot 9(9 \cdot 3) \\
28 \cdot 8(8 \cdot 5) \\
22 \cdot 0(8 \cdot 5)\end{array}$ & $\begin{array}{l}15 \cdot 2(4 \cdot 3) \\
15 \cdot 2(5 \cdot 0) \\
15 \cdot 1(5 \cdot 3)\end{array}$ & $\begin{array}{r}13 \cdot 2(7 \cdot 9) \\
13 \cdot 7(7 \cdot 6) \\
6 \cdot 7(4 \cdot 4)\end{array}$ & $\begin{array}{l}42 \cdot 7(8 \cdot 4) \\
43 \cdot 1(9 \cdot 0) \\
44 \cdot 5(9 \cdot 5)\end{array}$ & $\begin{array}{l}81 \cdot 9(9 \cdot 0) \\
81 \cdot 9(9 \cdot 7) \\
79 \cdot 5(12 \cdot 2)\end{array}$ & $\begin{array}{l}25 \cdot 8(21 \cdot 5) \\
32 \cdot 7(23 \cdot 5) \\
22 \cdot 4(22 \cdot 6)\end{array}$ & $\begin{array}{l}0.40(0 \cdot 27) \\
0 \cdot 40(0 \cdot 25) \\
0 \cdot 16(0 \cdot 14)\end{array}$ & $\begin{array}{l}45 \cdot 0(13 \cdot 2) \\
44 \cdot 6(12 \cdot 9) \\
32 \cdot 9(13 \cdot 0)\end{array}$ & $\begin{array}{l}0.99(0.31) \\
0.98(0.29) \\
0.79(0.20)\end{array}$ \\
\hline $\begin{array}{l}\text { colon to rectum } \dagger \\
\text { Changes with time after }\end{array}$ & - & 0.001 & $<0.001$ & NS & $<0.001$ & NS & NS & NS & $<0.001$ & $<0.001$ & $<0.001$ \\
\hline
\end{tabular}

^Maximum moving average smoothed over five cell positions.

†Mann-Whitney U test.

Kruskal-Wallis one way analysis of variance.

PLM=per cent bromodeoxyuridine labelled mitosis curve.

$0.5 \mathrm{ml}$ of $0.5 \%$ Tween 20 (Sigma) in PBS containing $0.5 \%$ normal goat serum and $25 \mu \mathrm{l}$ of the anti-BrdUrd antibody (Seralab). Incubation proceeded for one hour at room temperature.

Nuclei were then washed twice in PBS. Nuclei were resuspended in $0.5 \mathrm{ml} 0.5 \%$ Tween/normal goat serum in PBS and $25 \mu \mathrm{l}$ of goat anti-rat antibody-fluorescein isothiocyanate (FITC) conjugate (Sigma) for one hour at room temperature. Nuclei were then washed in PBS and resuspended in $2 \mathrm{ml}$ PBS with $20 \mu \mathrm{l}$ of $1.0 \mathrm{mg} / \mathrm{ml}$ propidium iodide (PI) (Sigma).

An Ortho Systems 50-H Cytofluorograph was used with a $5 \mathrm{~W}$ Argon ion laser which excites at $488 \mathrm{~nm}$ light wavelength. ${ }^{21}$ Green fluorescence (BrdUrd-FITC) was collected at 510-560 nm and red fluorescence (DNA-PI) above $620 \mathrm{~nm}$. Data for 10000 nuclei were collected in list mode. The data were gated to exclude multiple nuclei on the DNA peak versus area signal. The method of analysis used to calculate the $S$ phase duration, $T_{s}$, has been reported elsewhere. ${ }^{19}$ Because the flow cytometer does not distinguish between crypt and stromal cells, the machine cannot be used to measure the crypt labelling index unless a correction is made for the standard proportions of the cells based on manual counting of tissue sections. However, $S$ phase calculations based on the relative movement (mean DNA content) of labelled cells from S into G2 are applicable, because the large majority of $S$ phase cells are cryptal rather than stromal.

\section{STATISTICAL METHODS}

Comparisons between the various subgroups (area, age, and sex) were performed using the non-parametric Mann-Whitney $U$ test and Kruskal-Wallis one way analysis of variance. As there were significant differences between the

Human, bromodeoxyuridine in vivo

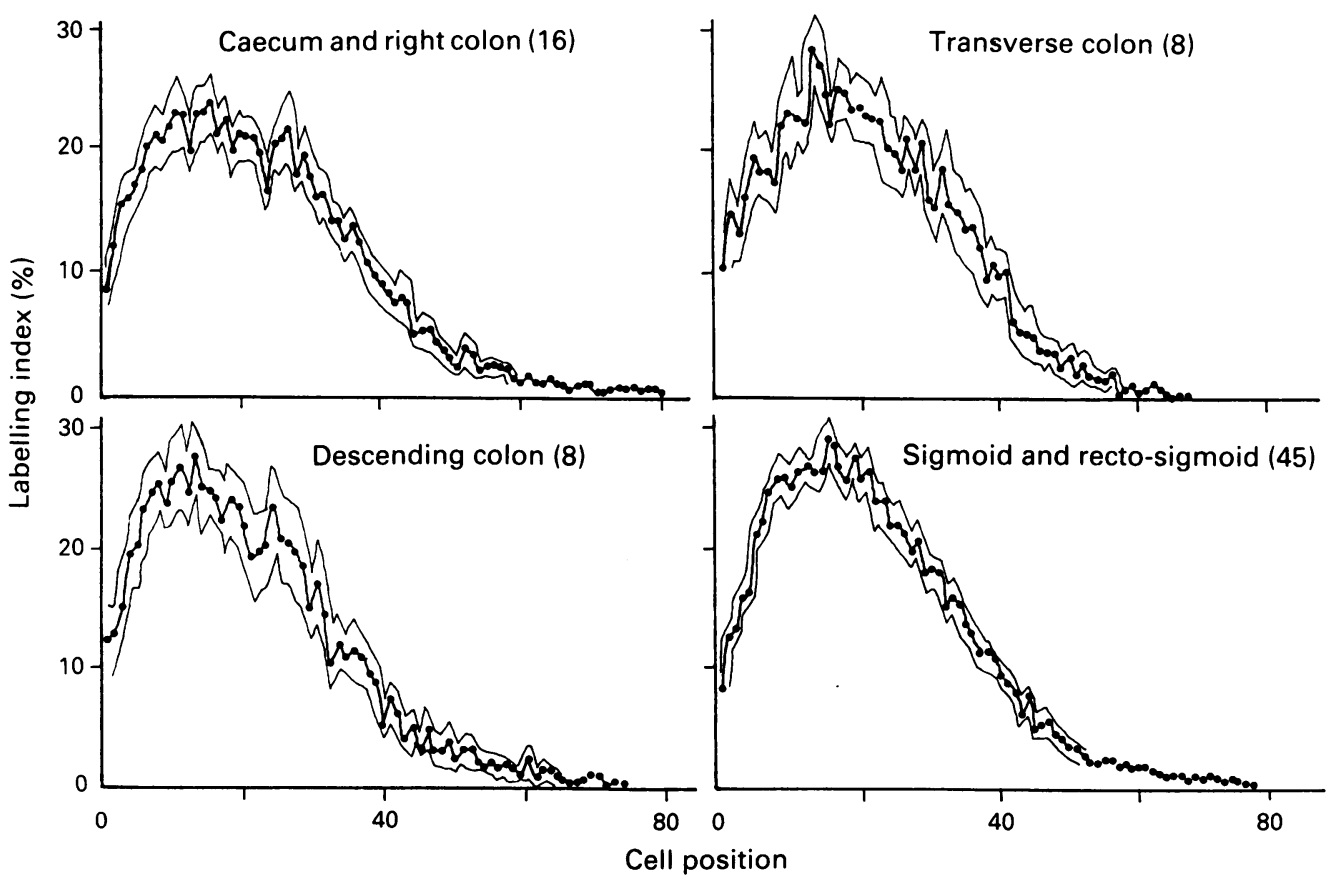

Figure 3: Actual labelling index frequency plots for four sites in the human large bowel. The number of samples analysed in each case is shown in parenthesis (see Table II for details). The standard error limits are shown by the upper and lower thin lines. 
rectal samples and the other areas, the rectal samples were treated separately in most of the analyses.

The effects of time were analysed using (i) Kruskal-Wallis tests on the data grouped into time bands; (ii) two way analysis of variance by area and time band; and (iii) linear regression against time with a term included to differentiate the rectal samples. An interaction term was considered but never reached significance. As the main effects of time would be expected during the earlier times, the regression was performed on all times $\leq 7$ hours and repeated for times $\leq 10$ hours. As there were no significant effects of time (other than on per cent labelled BrdUrd labelled mitosis curve) all time points were combined in the other analysis.

Heterogeneity was assessed using two way analysis of variance with area and patient, taking advantage of the fact that there were multiple samples from some patients. There were insufficient samples to allow the inclusion of a time factor in this analysis. A significance level of 0.05 was used throughout.

PER CENT LABELLED BrdUrd MITOSIS ANALYSIS A two way analysis of variance by time and area shows no significant difference in per cent labelled (BrdUrd) mitoses between the areas; therefore all areas were pooled. The curve was produced by pooling all the mitoses for all the patients sampled within successive one hour time bands. At later times larger time bands were used to increase the total number of mitoses assessed. A smooth curve drawn through the data was used as input to a modified version of the Gilbert ${ }^{25}$ program (SA Roberts, unpublished) and cell cycle parameters estimates obtained.

\section{Results}

\section{SPECIMENS STUDIED}

A total of 107 separate specimens of colorectal mucosa from 66 patients with adenocarcinomas were amenable to analysis. All were entirely normal by conventional histology. The samples were separated into seven different groups according to site. Since no significant differences were detected between the caecum and the right colon and since the distinction between these two areas is somewhat arbitrary, they were pooled. Similar reasoning led to us pool the data for the sigmoid and rectosigmoid junctional regions. This left us with five sites for comparison.

\section{PROLIFERATIVE PARAMETERS}

There were no significant differences by any criterion measured in any site in the colon (see Fig 3, Table II); these included the mean crypt length, total and peak labelling indices, and mitotic index. The mean (SD) crypt height in sections of the human large bowel (excluding the rectum) is $81.9(9.7)$ cells for the colon (all areas) and $79.5(12.2)$ cells for the rectum. The mean crypt circumference measured from 10 crypt cross sections in 10 patients is $41 \cdot 6(3.9)$ cells in

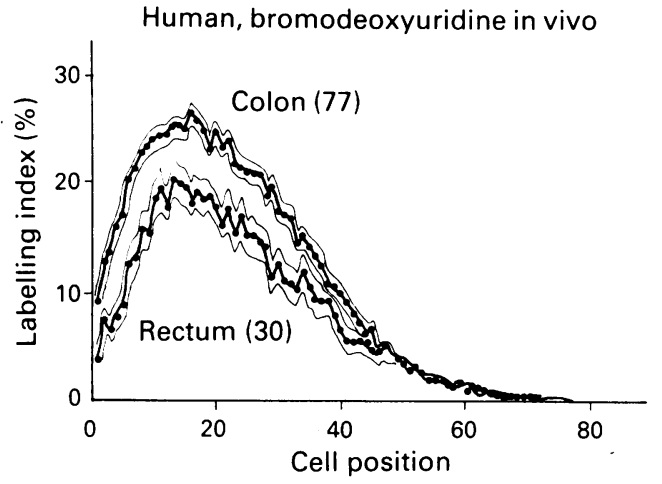

Figure 4: A comparison of the labelling index frequency plots for the colon ( 77 samples pooled) and the rectum ( 30 samples) (see Table II for details).

the sigmoid colon and $46.0(4 \cdot 4)$ cells in the rectum. This gives a total of 2044 cells per crypt in the colon and 2194 cells per crypt in the rectum, assuming a geometrical correction factor of $0 \cdot 6^{26}$ - human crypts are more than four times the size of mouse crypts. This value is close to the value obtained by Cheng $e t a l^{27}$ using squash preparations of whole cryts. In the colonic crypt some $10 \%$ (220) of cells will be in S phase and $0.4 \%$ (nine cells) in mitosis. Ninety per cent of labelled cells are found between cell positions 4 and 43. A measure of the maximum labelling is given by a moving 5 cell position smoothed average. This peak labelling index is about $30 \%$ and occurs at cell position 15 . The labelling index at the crypt base, the putative stem cell zone, is about $14 \%$.

Since there was no significant difference between any of the colonic sites they were pooled for comparison with the rectum which showed a significant difference in many of the parameters (see Fig 4, Table II). The rectal mucosal crypts contain approximately $30 \%$ fewer $S$ phase and mitotic cells. This may indicate either that the $T_{c}$ of rectal mucosa cells is longer than in the colon, or that there are fewer proliferating cells in the rectum - that is, it has a lower growth fraction. The power of the technique to detect changes in proliferation is illustrated by the comparison between rectum and colon. The differences between the mitotic index and labelling index values indicates that the BrdUrd labelling technique may be much more sensitive than any technique that relies on mitotic counting.

The mitotic index is low at $0.4 \%$ and is about $1 / 24$ th of the labelling index. Mitosis, and particularly the entry into $M$, may be very sensitive to oxygen and nutrient supply. Mitotic index would then be expected to fall rapidly with time after excision and before fixation. This could be the reason for the low or very variable mitotic indices in human tissue samples. ${ }^{28}$ However, if we assume (see below) that $T_{s}$ is 8.6 hours then the mitotic index data would suggest that the duration of $M$ is about 0.32 hours or 19.2 minutes, a time which is not unrealistic $\left(T_{m}=\right.$ $\mathrm{T}_{\mathrm{s}} \times \mathrm{MI} / \mathrm{LI}$ ). Furthermore, the time between surgery and fixation was usually short.

RELATION OF PROLIFERATION PATTERN TO TIME AFTER LABELLING

There was no significant relation between overall 
All areas, bromodeoxyuridine in vivo

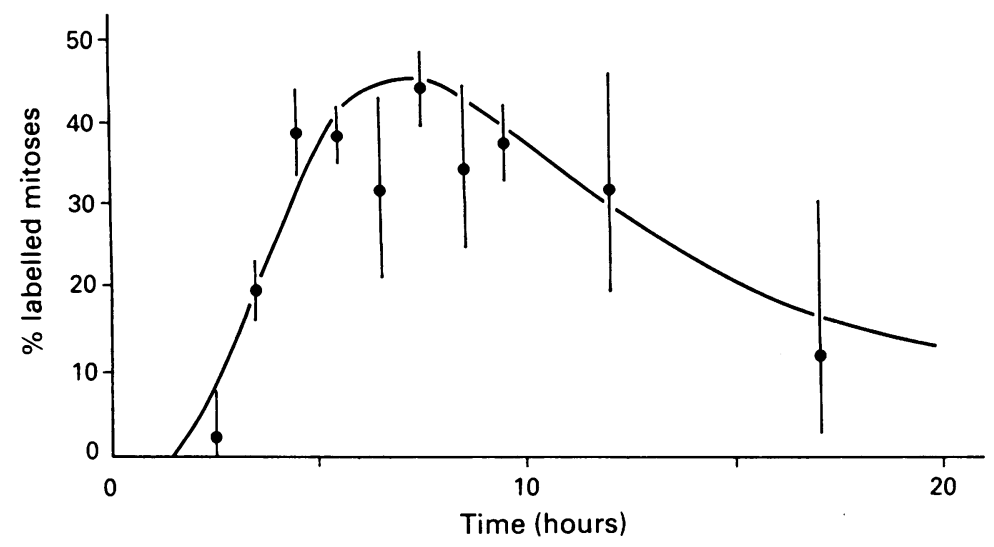

Figure 5: The percentage of bromodeoxyuridine labelled mitotic figures plotted against time after bromodeoxyuridine administration. Data have been pooled for all sites and for one hour intervals (se text for details) (mean (SE)).

labelling index or the clustering of labelled cells with time after injection although both labelling index and the frequency of labelled pairs increased with time. However, the data are not in ronsistent with an increase in labelling index with time of a magnitude expected based on the kinetics of the system. The per cent BrdUrd labelled mitosis curve did show a significant change with time (Fig 5). Analysis of this highly dampened curve using the Gilbert fitting programme $^{25}$ provided an estimate for $T_{s}$ of 4.9 hours (coefficient of variation of $T_{s}+G_{2}=67 \%$ ), 4.8 hours (coefficient of variation $=48 \%$ ) for $G_{2}$, and 38 hours (coefficient of variation $=67 \%$ ) for $T_{\mathrm{c}}$.

\section{CELL CYCLE PHASE DURATIONS}

The relation between the duration of the $S$ phase $\left(T_{s}\right)$ and the labelling index $(L I)$ is given by the following equation:

$$
\mathrm{LI}=\frac{\mathrm{N}_{\mathrm{s}}}{\mathrm{N}_{\mathrm{T}}}=\frac{\mathrm{T}_{\mathrm{s}}}{\mathrm{T}_{\mathrm{c}}} \times \mathrm{GF} \times \alpha
$$

where $N_{s}$ is the number of cells in $S$ and $N_{T}$ in the total number of cells counted. GF is the growth fraction which is unknown and $\alpha$ is a factor that takes into account the age distribution of cells throughout the cell cycle which is unknown in the present case but can be assumed to be unity. Similar relations hold for the duration of $M\left(T_{m}\right)$ and the mitotic index (MI). Finally, the relation between $\mathrm{LI}$ and $\mathrm{MI}$ is proportional to the relative durations of $T_{s}$ and $T_{m}$. In the absence of knowledge about GF and $\alpha$ the LI only provides information on the turnover time or doubling time $\mathrm{T}_{\mathrm{T}}\left(\mathrm{LI}=\mathrm{T}_{\mathrm{s}} / \mathrm{T}_{\mathrm{T}}\right)$.

The duration of the $S$ phase $\left(T_{s}\right)$ was calculated using flow cytometry from the relative movement of cells from $S$ to $G_{2}$ in the flow cytometric red (total DNA-PI) and green (BrdUrd labelled DNA-FITC) fluorescence distributions. ${ }^{19}$ This approach is unreliable for short time intervals after BrdUrd labelling as well as for long intervals (in excess of $T_{s}$ and $G_{2}$ ). Using data for intermediate times (3-10 hours) an estimate for $T_{s}$ of about $8.6(0.5)$ hours was obtained. Even within this time range, the estimated $T_{s}$ values showed a significant $(p=0.01)$ increase with time in a linear regression analysis, increasing by $0.69(0.26)$ hour per hour. The cause of this trend is not understood. Most published estimates for $T_{s}$ range between about 7 hours and 14 hours and for some calculations these extremes could be considered.

The turnover time $\left(T_{T}\right)$ of the whole crypt epithelium can thus be determined to be about 82 hours (3.41 days) from $T_{s} /$ overall average labelling index. The labelling index in the lower to mid-crypt region (cell positions $15-20$ ) is $28 \cdot 8$ for the colon and 22.0 for the rectum at cell position 15 in both cases. It is likely that the growth fraction in this mid-crypt region is close to unity and hence this labelling index can be used to determine a cell cycle time of 29.9 hours or $39 \cdot 1$ hours respectively. Such figures suggest that the overall growth fraction of crypts is 0.36 $0.48(29 \cdot 9$ or $39 \cdot 1 / 82)$. If we assume a $T_{s}$ as short as 7 hours the colonic cell cycle would reduce to $24 \cdot 3$ hours and if $T_{s}$ is as long as 14 hours it would be 48.6 hours for the colon. If $T_{s}$ is as short as 4.9 hours as suggested by the per cent BrdUrd labelled mitosis curve data (Fig 5) then the cell cycle in the mid-crypt could be as short as 17 hours.

\section{VARIABILITY}

There is significant inter- and intrapatient variability. The mean labelling index shows a $50 \%$ coefficient of variation between patients after accounting for the differences in gut area which is significantly greater than the $26 \%$ coefficient of variation within patients. The variation between samples from the same patient $(26 \%$ coefficient of variation) is significantly greater than the $5 \%$ expected simply from Poisson counting errors. This intrapatient heterogeneity can be brought about by either variability in the sample preparations and analysis, or real variability from site to site within the same region of the colon.

\section{Discussion}

TECHNIQUE

BrdUrd can be used as a substitute for $3 \mathrm{H}$ thymidine both in vitro and in vivo for histochemical mucosal proliferation studies. The use of BrdUrd to study $S$ phase labelling of tissue and tumour cells in vivo by histochemistry is a major advance over historical methods, particularly when combined with a semiautomated counting program for analysis such as that described. Productivity is much improved because the time delay in development of autoradiographs is circumvented. However, histological studies alone seriously under use the dynamic information which can be obtained from pulse labelling with BrdUrd in vivo if flow cytometry is also used. This and histochemistry are complementary techniques. However, the anatomical relations between labelled and unlabelled cells is lost in flow cytometry.

Multiparameter flow cytometry allows the estimation of the $S$ phase duration if certain assumptions are made. The first is that the bolus dose of BrdUrd is handled by mucosal cells as a true pulse label, and not stored for gradual 
incorporation into $S$ phase DNA or excised from the DNA with time..$^{29}$ Secondly, a linear incorporation of BrdUrd with time into $S$ phase cells is assumed. Thirdly, it is assumed that there is no cytoxicity - that is, that all labelled cells proceed through the cell cycle to division. Fourthly, the primary antibody binding to BrdUrd is assumed to be stoichiometric. Fifthly, all labelled and unlabelled cells are assumed to be crypt cells. These conditions may not be fully met in human intestinal mucosa. For example, the variable fraction of unlabelled $S$ phase cells seen in most histograms has not yet been satisfactorily explained. Moreover, a small but variable proportion of stromal cells such as lymphoid and connective tissue cells may contaminate the preparations. Generally the histologically determined labelling index values are higher, by factors of up to 4 , than the $S$ phase index determined by flow cytometry. The reasons for the difference remain obscure but are probably linked to the list of assumptions above. Differences of a similar magnitude have recently been reported for human tumour xenografts ${ }^{30}$ where it was possibly attributed to suboptimal staining for flow cytometry.

The presence of the BrdUrd $S$ phase label within tissues also provides a marker with which other proliferation associated antigens and cell proteins can be compared, and the relation of p62cmyc protein synthesis to BrdUrd labelling in this material is being undertaken.

\section{RESULTS}

Past studies of human mucosal kinetics have tended to report on a small series of patients using in vitro labelling and often unspecified sites (Table I). Published labelling index and $T_{s}$ values range widely, but our own extensive in vivo data lay at the median for both indices. This series is the largest yet reported of the proliferation characteristics of normal human colorectal mucosa. We acknowledge the possible criticism that all material was derived from patients with colorectal cancer and that in some way this tissue may differ from the normal human colon. However, detailed histological assessment has not shown any unusual features of this material, and all specimens were removed at least $5.0 \mathrm{~cm}$ from the primary carcinoma. We are currently studying the relation between mucosal proliferation and distance from the carcinoma and will report this in due course.

Our measurement of crypt length is somewhat greater than that in some published series. ${ }^{1231}$ This may be due to differences in defining the top of the crypt. We have standardised our crypt counting to a point beyond the inflexure of the crypt orifice as described. Differences may also have arisen in the selection criteria for counting crypts, and we emphasise the value of selecting good longitudinal crypts. A further source of variation lies in the method of handling overlapping nuclei. Our data are, however, consistent with absolute measurements of cells per crypt. ${ }^{27}$

The partial per cent BrdUrd labelled mitosis curve obtained is highly damped, with large coefficient of variations for all the parameters. In this situation particularly the curve does not extend much beyond the first peak, and one cannot expect very reliable estimates of cell cycle parameters. The large heterogeneity in kinetic parameters, while biologically realistic,-makes the estimates of the kinetic parameters sensitive to the exact functional form assumed for the distributions of the cell cycle parameters. We estimate that the parameters given are correct to within a factor of two, but would be reluctant to claim greater precision.

The systematic and standardised method of analysis of mucosal proliferation in vivo is a valuable tool for clinical studies of gastrointestinal diseases which are believed to be associated with altered proliferation - for example, familial polyposis coli, ulcerative colitis, and the putative mucosa-polyp-tumour proliferation sequence.

We have not so far identified any features of mucosal proliferation which may correlate with the development of a tumour. The colorectum is heterogeneous with regard to the risk of developing malignancy. For example, although $50 \%$ of all large bowel carcinomas develop at or below the rectosigmoid junction, ${ }^{32}$ virtually none arise in the more rapidly proliferating ileum. It is thus of interest that the proliferation characteristics of the colon are remarkably homogeneous along most of its length, and that the rectum seems to have a lower rate of proliferation than the colon but a higher cancer incidence.

We conclude that the combination of quantitative techniques that we have described offers substantial advantages for the study of colorectal mucosal proliferation, both in animal models and in human diseases where the clinical circumstances are appropriate. Our data will form the basis for further investigations into the relation between crypt cell turnover and colorectal proliferative diseases.

This work has been supported by the Cancer Research Campaign We thank Dr Nic McNally for his support and advice at the Gray Laboratory, and Mr R Stradling and Dr R Buchanan for assistance at St Mary's Hospital, Portsmouth, Department of Pathology. Miss Christine Whitsed assisted with the flow cytometry. Mr P C Weaver and Mr M R Thompson, St Mary's Hospital, and Professor Irving Taylor at the University Surgical Unit, Southampton, provided both support and access to patients under their care. We are particularly grateful to Caroline Chadwick and Dawn Hewitt at the Paterson Institute for their valuable technical assistance and to Kerry Baker for her patient help in preparing the manuscript.

1 Wright N, Alison M. The biology of epithelial cell populations. Oxford: Clarendon Press, 1984.

2 Potten CS, Hendry JH. Stem cells in the small intestine. In: Potten, CS, ed. Stem cells. Edinburgh: ChurchillIn: Potten, CS, ed. Stem

3 Potten CS, Hendry JH, Moore JV, Chwalinski S. Cytotoxic effects in gastro-intestinal epithelium (as exemplified by small intestine). In: Potten CS, Hendry JH, eds. Cytotoxic insult to tissue. Edinburgh: Churchill-Livingstone, 1983: $105-52$.

4 Serafini EP, Kirk AP, Chambers TJ. Rate and pattern of epithelial cell proliferation in ulcerative colitis. Gut 1981; 22: 648-52.

5 Bleiberg H, Mainguet P, Galand P, et al. Cell renewal in the human rectum; an in vitro autoradiographic study on active ulcerative colitis. Gastroenterology 1970; 58: 851-5.

6 Eastwood L, Trier JS. Epithelial cell renewal in cultured rectal biopsies in ulcerative colitis. Gastroenterology 1973; 64: 38390.

7 Bleiberg H, Mainguet P, Galyand P. Cell renewal in familial polyposis; comparison between polyps and adjacent health polyposis; comparison between polyps and
mucosa. Gastroenterology 1972; 63: 240-5.

8 Lightdale $C$, Lipkin $M$, Deschner $E$. In vivo measurements in familial polyposis: kinetics and location of proliferating cells in colonic adenomas. Cancer Res 1982; 42: 4280-3.

9 Chwalinski S, Potten CS, Evans G. Double labelling with bromodeoxyuridine and $3 \mathrm{H}$ - thymidine of proliferative cells in small intestinal epithelium in steady state and after irradiation. Cell Tissue Kinet 1988; 21 : 317-29.

10 Sunter JP, Watson AJ, Wright NA, Appleton DR. Cell proliferation at different sites along the length of the rat colon. Virchows Arch [B] 1979; 32: 75-87. 
11 Bleiberg H, Salahadin A, Galand P. Cell cycle parameters in human colon. Cancer 1977; 39: 1190-4.

12 Deschner EE, Maskens AP. Significance of the labelling index and labelling distribution as kinetic parameters in colorecta mucosa of cancer patients and DMH treated animals. Cancer 1982; 50: $1136-41$.

13 Terpestra OT, Blankenstein MV, Dees J, Eilers GAM. Abnormal pattern of cell proliferation in the entire colonic mucosa of patients with colon adenoma or cancer. Gastroenterology 1987; 92: 704-8.

14 Sunter JP, Wright NA, Appleton DR. Cell population kinetics in the epithelium of the colon of the male rat. Virchows Arch [B] 1978; 26: 275-87.

15 Cole JW, McKalen A. Studies on the morphogenesis of adenomatous polyps in the human colon. Gastroenterology 1961; 41: 122-5

16 Wynford-Thomas D, Williams ED. Use of bromodeoxyuridine for cell kinetic studies in intact animals. Cell Tissue Kinet 1986; 19: 179.

17 Risio M, Coverlizza S, Ferrari A, Candelaresi GL, Rossini FP. Immunohistochemical study of epithelial cell proliferation in hyperplastic polyps, adenomas, and adenocarcinomas of the large bowel. Gastroenterology 1988; 94: 899-906.

18 Khan S, Raza A, Petrelli N, Mittleman A. In vivo determination of labelling index of metastatic colorectal carcinoma and normal colonic mucosa using intravenous infusions of bromodeoxyuridine. F Surg Oncol 1988; 39: 114-8.

19 Begg AC, McNally NJ, Shrieve DC, Karcher H. A method to measure the duration of DNA synthesis from a single sample. Cytometry 1988; 6: 620-6.

20 Wilson GD, McNally NJ, Dunphy E, Karcher H, Pfrager R. The labelling index of human and mouse tumours assessed by $\mathrm{Br}$-Urd staining in vitro and in vivo and flow cytometry. Cytometry 1985;6:641-7.

21 Wilson GD, McNally NJ. Measurement of cell kinetics in human tumours in vivo using bromodeoxyuridine incorporation and flow cytometry. BrF Cancer 1988; 58: 423-31.

22 Rew DA, Wilson GD, Taylor I, Weaver PC. The in viv proliferation kinetics of human colorectal cancer. Br f Surg 1990; 78: 60-6.

23 Potten CS, Chwalinski S, Swindell R, Palmer M. The spatial organisation of the hierarchical proliferative cells of the crypts of the small intestine into clusters of synchronised cells. Cell Tissue Kinet 1982; 15: 351-70.

24 Kaur P, Potten CS. Circadian variation in migration velocity in small intestinal epithelium. Cell Tissue Kinet 1986; 19: 591-9.

25 Gilbert. The labelled mitosis curve and the estimation of the parameters of the cell cycle. Cell Tissue Kinet 1972; 5: 53-63.

26 Potten CS, Roberts SA, Chwalinski S, Loeffler M, Paulus U. The reliability in scoring mitotic activity in longitudinal sections of the crypts of the small intestine. Cell Tissue Kine 1988; 21: 231-46.

27 Cheng H, Bjerknes M, Amar J. Methods for the determination of epithelial cell kinetic parameters of human colonic epithelium isolated from surgical and biopsy specimens. Gastroenterology 1984; 86: 78-85.

28 Potten CS. Possible defects in the proliferative organisation and control mechanism in psoriasis. Proceedings of 4th International Psoriasis Symposiu

29 Saffhill R, Ockey CH. Strand breaks arising from the repair of the 5-bromodeoxyuridine-substituted template and methyl methanesulphonate-induced lesions can explain the formation of cistes chromatid exchanges. Chromosoma 1985; 92 218-24.

30 Parkins CS, Bush C, Price P, Steel GG. Cell proliferation in human tumour xenografts: measurement using antibody labelling against bromodeoxyuridine and Ki67. Cell Proliferation 1991; 24: 171-80.

31 Roncucci L, Maurizio P, et al. The influence of age on colonic epithelial cell proliferation. Cancer 1988; 62: 2373-1988.

32 Goligher JC. Surgery of the anus, rectum and colon. 4th ed. London: Baillière Tindall, 1980: 375-8.

33 Lipkin M. Cell proliferation in gastrointestinal disease. Nat Cancer Inst Monogr 1969; 30: 199-207.

34 Maskens AP. Distribution du compartiment proliferatif dans la muqueuse recto-colique normale, preneoplasique et neoplasique. ActaGastroenterol Belg 1978; XLI: 226-40.

35 Maskens AP, Deschner EE. Tritiated thymidine incorporation into epithelial cells of normal-appearing colorecta mucosa of cancer patients. F Natl Cancer Inst 1977; 58 : 1221-4.

36 Bleiberg $\mathrm{H}$, Galand $\mathrm{P}$. In vitro autoradiographic determination of cell kinetic parameters in adenocarcinomas and adjacent healthy mucosa of human colon and rectum. Cancer Res 1976; 36: 325-8.

37 Kanemitsu T, Akihiko K, Sadahiro Y. Study of the cell proliferation kinetics in ulcerative colitis, adenomatous proliferation kinetics in ulcerative colitis,

38 Lipkin M. Proliferation and differentiation of gastrointestinal cells in normal and disease states. In: Johnson LR, ed. Physiology of the gastrointestinal tract. New York: Raven Press, 1981: 145-68.

39 Shorter RG, Charles G, Moertel, Titus JL, Reitemeir RJ. Cell kinetics in the jejunum and rectum of man. Am $\mathcal{F}$ Dig Dis 1964; 9: 760-3.

40 Lipkin M. Cell replication in the gastrointestinal tract of man. Gastroenterology 1965; 48: 616-24.

41 Lipkin M, Bell B, Sherlock P. Generation time of epithelial cells in the human colon. Nature 1962; 195: 175-7.

42 Lipkin M, Bell B, Sherlock P. Cell proliferation kinetics in the gastrointestinal tract of man. Gastroenterology $1963 ; 45$ gastroi

43 Camplejohn RS. Cell Kinetics. Recent Results Cancer Res 1982; 83: 21-9.

44 Lipkin M, Bell B, Sherlock P. Cell proliferation kinetics in the gastrointestinal tract of man. 7 Clin Invest 1963; 42: 767-76. 